\title{
Cardio-Ankle Vascular Index and Its Potential Clinical Implications for Sleep Apnea
}

\author{
Kazuhiko Kotani \\ Department of Clinical Laboratory Medicine, Jichi Medical University, Shimotsuke-City, Japan
}

\section{Key Words}

Atherosclerosis · Arterial stiffness · Cardiovascular disease · Sleep disorder · Continuous positive airway pressure

\begin{abstract}
Sleep apnea is a prevalent disorder associated with an increased risk of cardiovascular disease (CVD). While arterial stiffness is a surrogate marker for the development of CVD, the cardioankle vascular index (CAVI) is a recently developed metric for evaluating arterial stiffness. Clinical studies have shown that the CAVI is higher in patients with the sleep apnea syndrome. In particular, a reduction in the CAVI can clearly be seen during short-term therapy for these patients. Although clinical evidence on sleep apnea using the CAVI is currently limited, the CAVI is expected to be useful for identifying patients with an increased risk of CVD and for monitoring treatment effectiveness in sleep apnea practice.

(C) 2014 S. Karger AG, Basel
\end{abstract}

\section{Sleep Apnea and Arterial Stiffness}

Sleep-related problems are common in modern society, and the sleep apnea syndrome (SAS) is a disorder associated with an increased risk of cardiovascular disease (CVD) [1-3]. Although the underlying mechanisms linking SAS and CVD remain to be clarified, structural and functional vascular damage caused by SAS (a condition of intermittent hypoxia and reoxygenation with the production of oxidative stress and inflammation as well as sympathetic overactivation) is attracting attention [1,2]. Several studies have reported a positive association between markers related to vascular damage, including arterial stiffness, and 
Table 1. Clinical studies of patients with SAS using the CAVI

\begin{tabular}{|c|c|c|c|c|c|c|}
\hline \multirow[t]{2}{*}{ Study } & \multirow[t]{2}{*}{ Study design } & \multicolumn{4}{|l|}{ Patients } & \multirow[t]{2}{*}{ Notes } \\
\hline & & group & $\mathrm{n}$ (male/female) & age, years & CAVI & \\
\hline $\begin{array}{l}\text { Kumagai } \\
\text { et al. [9] }\end{array}$ & Cross-sectional study & $\begin{array}{l}\text { Mild SAS } \\
\text { Moderate-to-severe SAS }\end{array}$ & $\begin{array}{c}74(60 / 14) \\
469(426 / 43)\end{array}$ & $\begin{array}{l}52.9 \\
53.7\end{array}$ & $\begin{array}{l}7.3 \\
7.7^{*}\end{array}$ & $\begin{array}{l}\text { The patients with SAS included } \\
\text { those with obstructive SAS }\end{array}$ \\
\hline \multirow[t]{2}{*}{$\begin{array}{l}\text { Kasai } \\
\text { et al. [10] }\end{array}$} & Cross-sectional study & $\begin{array}{l}\text { Control } \\
\text { Mild SAS } \\
\text { Moderate-to-severe SAS }\end{array}$ & $\begin{array}{l}25(25 /-) \\
23(23 /-) \\
27(27 /-)\end{array}$ & $\begin{array}{l}50.9 \\
51.0 \\
50.9\end{array}$ & $\begin{array}{l}6.85 \\
7.00 \\
7.68^{\#}\end{array}$ & $\begin{array}{l}\text { The patients with SAS included } \\
\text { those with obstructive SAS }\end{array}$ \\
\hline & $\begin{array}{l}\text { Intervention study } \\
\text { (single-arm) by 1-month } \\
\text { CPAP therapy }\end{array}$ & $\begin{array}{l}\text { Moderate-to-severe SAS (as } \\
\text { described above) }\end{array}$ & 27 & 50.9 & $\begin{array}{l}7.68 \text { at baseline; } \\
7.50 \text { at } 1 \text { month* }\end{array}$ & \\
\hline $\begin{array}{l}\text { Kato } \\
\text { et al. [11] }\end{array}$ & $\begin{array}{l}\text { Intervention study } \\
\text { (single-arm) by } 12 \text {-month } \\
\text { CPAP therapy }\end{array}$ & Moderate-to-severe SAS & $30(28 / 2)$ & 57.2 & $\begin{array}{l}7.80 \text { at baseline; } \\
7.56 \text { at } 1 \text { month*; } \\
7.72 \text { at } 12 \text { months }\end{array}$ & $\begin{array}{l}\text { The patients with SAS included } \\
\text { those with obstructive SAS }\end{array}$ \\
\hline $\begin{array}{l}\text { Yoshihisa } \\
\text { et al. [12] }\end{array}$ & $\begin{array}{l}\text { Intervention } \\
\text { (randomized-controlled) } \\
\text { study by 6-month ASV } \\
\text { therapy }\end{array}$ & $\begin{array}{l}\text { Heart failure with moderate- } \\
\text { to-severe sleep apnea, ASV } \\
\text { Non-ASV }\end{array}$ & $\begin{array}{l}18(16 / 2) \\
18(13 / 5)\end{array}$ & $\begin{array}{l}64.4 \\
64.3\end{array}$ & $\begin{array}{l}9.0 \text { at baseline; } \\
7.7 \text { at } 6 \text { months* } \\
8.5 \text { at baseline; } \\
8.5 \text { at } 6 \text { months }\end{array}$ & $\begin{array}{l}\text { The heart failure patients with } \\
\text { SAS included those with } \\
\text { obstructive SAS or Cheyne- } \\
\text { Stokes respiration with central } \\
\text { sleep apnea }\end{array}$ \\
\hline
\end{tabular}

${ }^{*} \mathrm{p}<0.05$ (vs. counterpart group or baseline), ${ }^{*} \mathrm{p}<0.05$ (vs. control or mild SAS).

the disease severity [2] as well as a favorable effect of continuous positive airway pressure (CPAP - a treatment modality for SAS) on the vascular markers among patients with SAS [2, 4-6]. Increased arterial stiffness can reflect not only structural but also functional vascular damage, so the effect of CPAP on arterial stiffness is thought to be due to improvements in functional damage associated with muscular arterial stiffness and endothelial dysfunction [7]. The present knowledge indicates the importance of evaluating arterial stiffness for managing CVD risks in the clinical practice of SAS.

Various methods have been developed for evaluating arterial stiffness, such as the pulse wave velocity (PWV), the augmentation index, and the stiffness parameter $\beta$. These methods are noninvasive and relatively easy to perform but have technical and practical issues in accurately measuring arterial stiffness [8]. To resolve these issues, the cardio-ankle vascular index (CAVI) was developed based on the PWV and stiffness parameter $\beta$ [8]. One feature of the CAVI is the minor influence of blood pressure at the time of measurement, a crucial confounder for the management of SAS and its related CVD risks [9]. Therefore, an accumulation of clinical evidence with a more accurate evaluation of arterial stiffness as measured by the CAVI is currently expected among patients with SAS associated with CVD.

\section{Clinical Studies on SAS Using the CAVI}

There have been clinical studies of patients with SAS using the CAVI (table 1). The first study [9] showed the possible usefulness of CAVI measurements in patients with obstructive SAS. That study confirmed the good reproducibility of the CAVI measurement in these patients with a coefficient of variation of 2.8 as well as weak or nonsignificant correlations between the CAVI and blood pressure levels. It was also demonstrated that patients with a moderateto-severe state defined as an apnea-hypopnea index of $\geq 15$ events $/ \mathrm{h}(\mathrm{n}=469$, male $=91 \%$, mean age $=53.7$ years) had a significantly higher CAVI (7.7 vs. 7.3) than those with a mild state defined as an apnea-hypopnea index of $\geq 5$ and $<15$ events $/ \mathrm{h}(\mathrm{n}=74$, male $=81 \%$, mean age $=52.9$ years) $[9]$. 
A subsequent study [10] examined the difference in the CAVI by severity among male patients with obstructive SAS. Patients with a moderate-to-severe state $(\mathrm{n}=27$, mean age $=$ 50.9 years) had a significantly higher CAVI ( 7.68$)$ than patients with a mild state $(n=23$, mean age $=51.0$ years, $C A V I=7.00)$ or controls matched for age and body mass index $(n=25$, mean age $=50.9$ years, CAVI $=6.85$ ) [10]. When CPAP therapy was applied to those with a moderateto-severe state, the CAVI was significantly reduced from 7.68 to 7.50 after 1 month of therapy [10].

An additional study investigated the change in the CAVI during a 12-month CPAP therapy in patients with a moderate-to-severe state of obstructive SAS $(n=30$, male $=93 \%$, mean age $=57.2$ years) [11]. That study showed that the CAVI was significantly reduced from 7.80 at baseline to 7.56 after 1 month of CPAP therapy, while a nonsignificant reduction of the CAVI (to 7.72) was observed after 12 months of CPAP therapy. The authors stated that the 12 month change in the CAVI could be affected by the natural progression of the aging process. When the factors that were significantly correlated with the 12-month change in the CAVI were analyzed, the results suggested that long-term CPAP therapy might be effective for maintaining the CAVI below the baseline levels when it was linked with CPAP compliance, glycemic control, and antihypertensive medications such as angiotensin-converting enzyme inhibitors or angiotensin-II receptor blockers [11].

A recently published study examined the change in the CAVI by adaptive servoventilation (ASV) therapy among heart failure patients with preserved left ventricular ejection fraction [12]. These patients had a moderate-to-severe state of obstructive SAS or Cheyne-Stokes respiration with central sleep apnea $(n=36$, male $=81 \%$, mean age $=64.3$ years $)$ and were randomly assigned to either the ASV-treated group or the non-ASV-treated group [12]. The CAVI was significantly reduced from 9.0 at baseline to 7.7 after 6 months of therapy in the ASV-treated group, while it had not changed after 6 months in the non-ASV-treated group (8.5 at both time points) [12]. Cardiac event-free (without cardiac death and worsening heart failure) rates during a follow-up period of 543 days were also higher in the ASV-treated group [12].

\section{Perspectives on the CAVI in Sleep Apnea Practice}

While limited clinical data on SAS using the CAVI are currently available, increased arterial stiffness, as assessed by the CAVI, has been associated with the disease severity of SAS. In particular, a reduction in the CAVI can clearly be seen during a short-term period of the therapy for these patients. The CAVI seems to be a potentially useful way for identifying patients at risk for CVD and for possibly monitoring therapy in sleep apnea practice. On the other hand, since there has been still substantial evidence proving a reduction in CVD events among SAS patients with the management of the CAVI, the clinical utility of measuring the CAVI in sleep apnea clinics has yet to be definitively established in large prospective clinical trials.

\section{References}

1 Kohler M, Stradling JR: Mechanisms of vascular damage in obstructive sleep apnea. Nat Rev Cardiol 2010;7: 677-685.

2 Drager LF, Polotsky VY, Lorenzi-Filho G: Obstructive sleep apnea: an emerging risk factor for atherosclerosis. Chest 2011;140:534-542.

- 3 Mannarino MR, Di Filippo F, Pirro M: Obstructive sleep apnea syndrome. Eur J Intern Med 2012;23:586-593.

4 Kitahara Y, Hattori N, Yokoyama A, Nakajima M, Kohno N: Effect of CPAP on brachial-ankle pulse wave velocity in patients with OSAHS: an open-labelled study. Respir Med 2006;100:2160-2109. 
5 Phillips CL, Yee B, Yang Q, Villaneuva AT, Hedner J, Berend N, et al: Effects of continuous positive airway pressure treatment and withdrawal in patients with obstructive sleep apnea on arterial stiffness and central BP. Chest 2008;134:94-100.

6 Shiina K, Tomiyama H, Takata Y, Yoshida M, Kato K, Saruhara H, et al: Effects of CPAP therapy on the sympathovagal balance and arterial stiffness in obstructive sleep apnea. Respir Med 2010;104:911-916.

- 7 Zieman SJ, Melenovsky V, Kass DA: Mechanisms, pathophysiology, and therapy of arterial stiffness. Arterioscler Thromb Vasc Biol 2005;25:932-943.

8 Shirai K, Hiruta N, Song M, Kurosu T, Suzuki J, Tomaru T, et al: Cardio-ankle vascular index (CAVI) as a novel indicator of arterial stiffness: theory, evidence and perspectives. J Atheroscler Thromb 2011;18:924-938.

9 Kumagai T, Kasai T, Kato M, Naito R, Maeno K, Kasagi S, et al: Establishment of the cardio-ankle vascular index in patients with obstructive sleep apnea. Chest 2009;136:779-786.

10 Kasai T, Inoue K, Kumagai T, Kato M, Kawana F, Sagara M, et al: Plasma pentraxin3 and arterial stiffness in men with obstructive sleep apnea. Am J Hypertens 2011;24:401-407.

-11 Kato M, Kumagai T, Naito R, Maeno K, Kasagi S, Kawana F, et al: Change in cardio-ankle vascular index by longterm continuous positive airway pressure therapy for obstructive sleep apnea. J Cardiol 2011;58:74-82.

-12 Yoshihisa A, Suzuki S, Yamaki T, Sugimoto K, Kunii H, Nakazato K, et al: Impact of adaptive servo-ventilation on cardiovascular function and prognosis in heart failure patients with preserved left ventricular ejection fraction and sleep-disordered breathing. Eur J Heart Fail 2013;15:543-545. 